\title{
PENGARUH PEMBERIAN PUPUK ORGANIK CAIR DAN DOSIS PUPUK NPK (15:15:15) TERHADAP PERTUMBUHAN DAN PRODUKSI TANAMAN MENTIMUN (Cucumis sativus L.)
}

\author{
Hasyiatun Y. Kurniawati, Agus Karyanto \& Rugayah \\ Jurusan Agroteknologi, Fakultas Pertanian Universitas Lampung \\ Jl. Prof. Dr. Soemantri Brodjonegoro no. 1 Bandar Lampung 35145
}

\begin{abstract}
ABSTRAK
Mentimun (Cucumis sativus L.) merupakan salah satu tanaman sayuran yang memiliki banyak manfaat salah satunya yaitu sebagai detoksifikasi atau peluruh racun dari dalam tubuh. Banyaknya manfaat tersebut mengakibatkan permintaan mentimun semakin meningkat, namun tidak diimbangi dengan produksi yang baik. Untuk itu perlu dilakukan budidaya yang baik agar kebutuhan buah mentimun terpenuhi. Penelitian ini bertujuan untuk mengetahui pengaruh pemberian pupuk organik cair terhadap pertumbuhan dan produksi tanaman mentimun, pengaruh dosis pupuk NPK yang memberikan pengaruh terbaik terhadap pertumbuhan dan produksi tanaman mentimun, dan pengaruh pemberian pupuk organik terhadap pertumbuhan dan produksi tanaman mentimun pada masing - masing dosis NPK. Penelitian ini dilaksanakan di rumah kaca laboratorium Lapangan Terpadu Universitas Lampung mulai dari bulan Maret sampai Juni 2012. Perlakuan dalam penelitian ini disusun secara faktorial (2x3) dalam rancangan teracak sempurna dengan tiga ulangan. Perlakuan faktorial terdiri dari dua faktor, faktor pertama adalah pemberian pupuk organik cair (A), yaitu tanpa pupuk organik cair $\left(a_{1}\right)$ dan dengan pupuk organik cair $\left(a_{2}\right)$. Faktor kedua adalah dosis pupuk NPK $(B)$, yaitu $10 \mathrm{~g}$ per polibag $\left(b_{1}\right), 20 \mathrm{~g}$ per polibag $\left(b_{2}\right)$, dan $30 \mathrm{~g}$ per polibag $\left(b_{3}\right)$. Hasil penelitian menunjukkan bahwa pemberian pupuk NPK (15:15:15) dengan dosis $20 \mathrm{~g}$ per polibag dan $30 \mathrm{~g}$ per polibag memberikan hasil yang lebih tinggi bagi pertumbuhan dan produksi tanaman mentimun dibandingkan dengan pemberian NPK dosis $10 \mathrm{~g}$ per polibag, khususnya pada jumlah daun, jumlah bunga jantan, jumlah bunga betina, jumlah buah per tanaman, bobot buah per tanaman, panjang buah, dan bobot kering brangkasan tanaman mentimun, dan pengaruh pemberian pupuk organik cair terhadap pertumbuhan tanaman mentimun dipengaruhi oleh pemberian pupuk NPK $(15: 15: 15)$ hanya nampak pada variabel jumlah bunga jantan.
\end{abstract}

Kata kunci: mentimun, NPK, pupuk organik cair.

\section{PENDAHULUAN}

Produksi mentimun di Indonesia dari tahun ke tahun masih fluktuatif. Data dari tahun 2004 hingga 2010 menunjukkan bahwa produksi mentimun di Indonesia mengalami peningkatan yaitu 477,716 ton pada tahun 2004 menjadi 552,891 ton pada tahun 2005 dan 598,890 ton pada tahun 2006. Namun produksi mentimun menurun pada tahun 2007, 2008 dan 2010 (BPS, 2012).

Rendahnya produktivitas tanaman mentimun di Indonesia dapat disebabkan oleh beberapa faktor di antaranya adalah faktor iklim, teknik bercocok tanam seperti pengolahan tanah, pemupukan, pengairan, serta adanya serangan hama dan penyakit (Sumpena, 2001). Pada musim hujan produksi mentimun lebih rendah dibandingkan musim kemarau, karena curah hujan yang terlalu tinggi dapat menyebabkan bunga tanaman mentimun gugur (Septiyaning, 2011). Produksi mentimun dapat ditingkatkan dengan cara pemupukan yang tepat. Pemupukan perlu dilakukan karena kandungan hara dalam tanah selalu berkurang akibat diserap oleh tanaman. Secara umum ada dua jenis pupuk, yaitu pupuk organik dan pupuk anorganik. Pupuk organik adalah pupuk yang tersusun dari materi makhluk hidup, seperti pelapukan sisa-sisa tanaman, hewan, dan manusia. Pupuk organik dapat berbentuk padat atau cair yang digunakan untuk memperbaiki sifat fisik, kimia, dan biologi tanah.

Pupuk organik cair adalah larutan dari pembusukan bahan-bahan organik yang berasal dari sisa tanaman, kotoran hewan, dan manusia yang kandungan unsur haranya lebih dari satu unsur. Menurut Simarmata (2005), pupuk organik cair merupakan hasil fermentasi dari berbagai bahan organik yang mengandung berbagai macam asam amino, fitohormon, dan vitamin yang 
berperan dalam meningkatkan dan merangsang pertumbuhan mikroba maupun rhizosfir tanah. Pupuk organik cair juga biasanya banyak mengandung mikroba yang berfungsi menambat $\mathrm{N}$ dan pelarut $\mathrm{P} \& \mathrm{~K}$, meningkatkan kadar unsur hara makro dan mikro secara alami dengan cepat yang sangat dibutuhkan oleh tanaman dan lingkungan, serta memacu percepatan proses keluarnya akar, pertumbuhan, pembungaan dan pembuahan. Selain itu pemberian pupuk organik cair pada tanaman tidak akan meninggalkan residu pada hasil tanaman sehingga aman bagi kesehatan manusia (Hamdani dan Simarmata, 2003).

Selain pupuk organik, pemberian pupuk anorganik juga perlu dilakukan agar tersedianya unsur hara yang cukup dan seimbang di dalam tanah. Aplikasi pupuk anorganik terutama dilakukan untuk menyediakan unsur hara $\mathrm{N}, \mathrm{P}$, dan $\mathrm{K}$ baik dalam bentuk pupuk tunggal ataupun majemuk. Salah satu pupuk majemuk yang biasa digunakan petani adalah pupuk majemuk NPK Mutiara 15:15:15 (mengandung 15\% N, 15\% $\mathrm{P}_{2} \mathrm{O}_{5}$, dan $\left.15 \% \mathrm{~K}_{2} \mathrm{O}\right)$. Hal ini berarti pupuk NPK mutiara mengandung unsur hara makro seimbang yang baik bagi pertumbuhan tanaman. Namun tanaman juga membutuhkan unsur hara mikro yang tidak banyak didapat pada pupuk NPK. Untuk itu penggunaan pupuk anorganik perlu dipadukan dengan pengunaan pupuk organik cair agar dapat menambah unsur hara yang dibutuhkan tanaman dan sekaligus meningkatkan sumber bahan organik tanah. Farida dan Hamdani (2001) menyatakan bahwa pemberian pupuk organik yang dikombinasikan dengan pupuk anorganik, dapat meningkatkan produktivitas tanaman dan dapat meningkatkan efisiensi penggunaan pupuk. Penelitian ini bertujuan untuk mengetahui pengaruh pemberian pupuk organik cair terhadap pertumbuhan dan produksi tanaman mentimun pada masing-masing dosis NPK

\section{BAHAN DAN METODE}

Penelitian ini dilaksanakan di rumah kaca laboratorium Lapangan Terpadu Universitas Lampung kampus Gedong Meneng, Bandar Lampung, mulai dari bulan Maret sampai Juni 2012. Bahan yang digunakan dalam penelitian adalah benih mentimun cv MISANO, pupuk NPK 15:15:15, pupuk organik cair Bio-Extrim, cairan metal eugenol, dan insektisida.

Perlakuan dalam penelitian ini disusun secara faktorial $(2 \times 3)$ dalam rancangan teracak sempurna dengan tiga ulangan. Perlakuan faktorial terdiri dari dua faktor, faktor pertama adalah pemberian pupuk organik cair (A), yaitu tanpa pupuk organik cair $\left(\mathrm{a}_{1}\right)$ dan dengan pupuk organik cair $\left(\mathrm{a}_{2}\right)$. Faktor kedua adalah dosis pupuk
NPK (B), yaitu $10 \mathrm{~g}$ per polibag $\left(\mathrm{b}_{1}\right), 20 \mathrm{~g}$ per polibag $\left(b_{2}\right)$, dan $30 \mathrm{~g}$ per polibag $\left(\mathrm{b}_{3}\right)$. Pengamatan dilakukan pada setiap petak yang berjumlah tiga tanaman. Setelah data terkumpul, homogenitas ragam antar perlakuan diuji dengan uji Bartlet dan aditivitas data diuji dengan uji Tukey. Bila kedua asumsi terpenuhi, maka pemisahan nilai tengah dilakukan dengan menggunakan uji Beda Nyata Terkecil (BNT) pada taraf á 5\%.

Media tanam yang digunakan adalah campuran tanah dan pupuk kandang sapi dengan perbandingan yaitu $2: 1$ (volume/volume). Tanah dan pupuk kandang yang telah dicampur rata kemudian dimasukkan ke dalam polibag berukuran $5 \mathrm{~kg}$ hingga $3 / 4$ bagian. Penanaman dilakukan dengan menanam dua butir benih timun hibrida varietas Misano pada setiap polibag, kemudian dipilih satu tanaman yang tumbuhnya lebih baik. Pupuk yang diberikan adalah pupuk NPK $15: 15: 15$ dan pupuk organik cair yang diberikan sebagai perlakuan. Pupuk NPK $15: 15: 15$ diberikan pada 1 minggu setelah tanam (mst) sesuai dengan perlakuan, yaitu dengan dosis $10 \mathrm{~g}$ per polibag, $20 \mathrm{~g}$ per polibag, dan $30 \mathrm{~g}$ per polibag pupuk organik cair diberikan $2 \mathrm{kali}$, aplikasi pertama dilakukan pada 2 minggu setelah tanam dan aplikasi kedua pada dua minggu setelah aplikasi petama (4 minggu setelah tanam), yaitu telah memasuki fase generatif dengan konsentrasi $5 \mathrm{ml} \mathrm{l}^{-1}$. Pupuk organik cair diberikan dengan cara disiramkan ke polibag sebanyak $500 \mathrm{ml}$ per polibag, sedangkan perlakuan kontrol hanya disiram dengan air. Pengendalian hama penyakit tanaman dengan cara penyemprotan pestisida dan memasang perangkap lalat buah. Pemasangan ajir dilakukan sedini mungkin agar tidak merusak akar tanaman. Variabel yang diamati adalah jumlah daun, jumlah cabang, jumlah bunga jantan, jumlah bunga betina, jumlah buah per tanaman, jumlah buah yang rusak dan gugur, bobot buah per tanaman, panjang buah, diameter buah, rasio panjang dan diameter buah, dan bobot kering berangkasan.

\section{HASIL DAN PEMBAHASAN}

Hasil penelitian menunjukkan bahwa perlakuan pemberian pupuk organik cair tidak berpengaruh nyata pada semua variabel pengamatan yaitu jumlah daun, jumlah cabang, jumlah bunga jantan, jumlah bunga betina, jumlah buah pertanaman, jumlah buah rusak dan gugur, panjang buah, diameter buah, bobot buah, serta rasio panjang dan diameter buah, dan bobot kering brangkasan. Hal ini kemungkinan disebabkan oleh waktu pemberian pupuk organik cair yang kurang tepat pada tanaman mentimun. Pada penelitian ini pemberian pupuk organik cair dilakukan pada 2 dan 4 minggu setelah 
tanam, sehingga pangaruh yang diberikan sangat lambat dan tidak nampak pada pertumbuhan tanaman mentimun.

Pupuk organik cair yang diberikan pada saat tanam bermanfaat sebagai nutrisi pada masa awal pertumbuhan tanaman mentimun yang merupakan tanaman semusim dan memiliki siklus hidup yang relatif pendek, yaitu 4560 hari. Dalam penelitian ini, belum terlihat respon akibat pemberian pupuk organik cair, oleh sebab itu pemberian pupuk organk cair pada tanaman mentimun sebaiknya dilakukan pada saat tanam, sehingga unsur hara telah tersedia ketika tanaman memasuki fase pertumbuhan vegetatif awal sebelum memasuki fase generatif, serta frekuensi pemberian yang lebih sering yaitu seminggu sekali.

Hasil penelitian ini sejalan dengan penelitian Rohayati (2007) yang menyatakan bahwa, pemberian pupuk organik cair tidak meningkatkan hasil tanaman kentang. Namun dalam penelitian Nurhayati (2012), pemberian pupuk organik cair dengan interval waktu yang berbeda, berpengaruh nyata terhadap tinggi tanaman pada 4 MST, dan bobot umbi tanaman kentang. Hamdani (2008), juga menyatakan bahwa pemberian pupuk organik cair berpengaruh nyata terhadap bunga jadi buah, jumlah buah per tanaman, bobot buah per tanaman, hasil per petak, dan hasil per hektar serta meningkatkan hasil produksi tanaman mentimun.Menurut Sutejo dan Kartasapoetra (1995), kebutuhan berbagai macam unsur hara pada tanaman dalam masa pertumbuhan dan perkembangan tidaklah sama, yaitu membutuhkan waktu pemberian dan dosis yang berbeda, sehingga pemupukan sebaiknya diberikan pada saat tanaman memerlukan unsur hara secara intensif agar pertumbuhan dan perkembangannya berlangsung dengan baik.
Pupuk organik cair yang digunakan pada penelitian ini mengandung unsur hara makro $(\mathrm{N}, \mathrm{P}, \mathrm{K})$ dan juga bakteri pelarut fosfat, Rhizobium sp., Azospirillum sp., dan Azotobakter sp. sehingga dapat meningkatkan pertumbuhan tanaman mentimun. Menurut Sutanto (2002), keuntungan bakteri Azospirillum sp. dalam tanah adalah apabila saat berasosiasi dengan perakaran tanaman yang tidak dapat menambat nitrogen, maka bakteri Azospirillum sp. dapat meningkatkan penyerapan nitrogen yang ada di dalam tanah, tetapi apabila berasosiasi dengan perakaran tanaman yang mampu menambat nitrogen, maka nitrogen di dalam tanah dapat dipertahankan dalam waktu yang relatif lebih lama. Pemberian pupuk organik cair yang mengandung bakteri pelarut fosfat juga dapat meningkatkan ketersediaan $\mathrm{P}$ dan meningkatkan efisiensi penggunaan pupuk anorganik NPK menjadi $3 / 4$ takaran NPK.

Menurut Indrakusuma (2000), pupuk organik cair dapat memperbaiki sifat fisik, kimia, dan biologi tanah, sehingga dapat meningkatkan produksi tanaman, meningkatkan kualitas produk tanaman dan mengurangi penggunaan pupuk anorganik. Adanya kombinasi antara pupuk organik cair dan NPK diharapkan mampu meningkatkan serapan unsur hara pupuk NPK pada dosis yang diberikan, karena pupuk organik cair ini mengandung mikroorganisme yang membantu dalam penyerapan unsur hara. Peningkatan serapan unsur hara $\mathrm{N}, \mathrm{P}, \mathrm{K}$ maka mampu meningkatkan pertumbuhan vegetatif tanaman mentimun, namun hasil penelitian ini tidak menunjukkan adanya interaksi antara pupuk organik cair dan dosis pupuk NPK terhadap variabel pertumbuhan vegetatif tanaman, tetapi hanya pada variabel jumlah bunga jantan yang muncul pada setiap tanaman (Tabel 1).

Tabel 1. Pengaruh pupuk organik cair dan dosis pupuk NPK (15:15:15) terhadap jumlah bunga jantan tanaman mentimun.

\begin{tabular}{lccc}
\hline Pupuk organik & \multicolumn{3}{c}{ Dosis NPK } \\
\cline { 2 - 4 } & $10 \mathrm{~g} /$ polibag & $20 \mathrm{~g} /$ polibag & $30 \mathrm{~g} /$ polibag \\
\hline Tanpa pupuk organik & $2,90 \mathrm{c}$ & $23,00 \mathrm{a}$ & $18,23 \mathrm{~b}$ \\
& $(\mathrm{a})$ & $(\mathrm{a})$ & $(\mathrm{a})$ \\
Dengan pupuk organik & $6,80 \mathrm{~b}$ & $14,57 \mathrm{a}$ & $19,00 \mathrm{a}$ \\
& $(\mathrm{a})$ & $(\mathrm{b})$ & (a) \\
\hline BNT 0,05 & 6,18 & &
\end{tabular}

Keterangan : Angka - angka yang diikuti oleh huruf yang sama tidak berbeda nyata dengan uji BNT pada taraf $5 \%$. Huruf dengan tanda kurung dibaca secara vertikal dan huruf tanpa tanda kurung dibaca secara horizontal. 
Hal ini kemungkinan disebabkan oleh pemberian pupuk kandang sapi yang dicampurkan sebagai media tanam. Kandungan bahan organik pada media tanam yang telah dicampur pupuk kandang sapi cukup meningkatkan ketersediaan unsur hara yang dibutuhkan oleh tanaman mentimun. Oleh karena itu, kombinasi pemberian pupuk organik cair dan dosis pupuk NPK (15:15:15) tidak menunjukkan hasil yang signifikan. Nurshanti (2009) menyatakan bahwa, pemberian pupuk organik kotoran kambing, kotoran sapi dan kotoran ayam berpengaruh terhadap beberapa variabel pertumbuhan vegetatif tanaman sawi caisim yaitu tinggi tanaman, jumlah daun, luas daun dan bobot basah berangkasan.

Perlakuan pemberian pupuk NPK (15:15:15) pada penelitian ini memberikan pengaruh nyata pada variabel jumlah daun, jumlah bunga jantan, jumlah bunga betina, jumlah buah pertanaman, jumlah buah rusak dan gugur, bobot buah, panjang buah, dan bobot kering brangkasan (Tabel 2). Hasil penelitian ini sejalan dengan penelitian Tuherkih (2010) menyatakan bahwa, penggunaan pupuk majemuk NPK (16:16:15) dapat meningkatkan serapan $\mathrm{N}$, P dan K serta meningkatkan hasil produksi tanaman mentimun. Pada penelitian ini pemberian pupuk NPK dengan dosis $20 \mathrm{~kg} /$ polibag memberikan pengaruh terbaik dibandingkan dengan perlakuan lainnya. Hal ini mengindikasikan bahwa unsur hara makro yang terkandung dalam pupuk majemuk tersebut berperan dalam mendukung pertumbuhan dan hasil produksi tanaman mentimun, karena unsur hara yang dibutuhkan tanaman tersedia dalam jumlah yang berimbang.
Suwarno (2013) menyatakan bahwa tanaman akan tumbuh subur apabila unsur hara yang dibutuhkan tanaman tersedia dalam proporsi yang seimbang terutama unsur hara makro seperti N, P dan K.

Menurut Setyati dalam Sudjianto dkk. (2009), pupuk NPK mempunyai peranan dalam memacu dan meningkatkan pertumbuhan dan hasil tanaman apabila aplikasinya tepat dan tidak berlebihan, karena dengan dosis yang tepat maka akan memberikan hasil yang optimal pada tanaman. Menurut Lubis dalam Suwarno (2013), pemberian pupuk majemuk NPK berpengaruh nyata terhadap bobot buah per sampel tanaman terung. Sarno (2009), dalam penelitiannya juga menyatakan bahwa pemberian pupuk majemuk NPK dapat meningkatkan kadar P-tersedia dan K-dd tanah, sehingga pertumbuhan dan produksi tanaman caisim menjadi meningkat. Hal ini disebabkan karena unsur hara makro yang di kandung pupuk majemuk NPK memiliki peranan yang berbeda dalam proses metabolisme tumbuhan. Unsur $\mathrm{N}$ berperan dalam pembentukan klorofil yang bermanfaat dalam proses fotosintesis, apabila fotosintesis lancar maka semakin banyak karbohidrat yang akan dihasilkan. Unsur P berperan sebagai bahan dasar pembentukan ATP dan ADP yang dibutuhkan dalam proses metabolisme untuk pembentukan asam amino, tepung, lemak dan senyawa organik lainnya. Sedangkan unsur K berperan sebagai activator berbagai jenis enzim yang membantu pembentukan protein dan karbohidrat sekaligus memperkuat tubuh tanaman seperti daun, bunga dan buah sehingga tidak mudah gugur.

Tabel 2. Pengaruh pupuk organik cair dan dosis pupuk NPK (15:15:15) terhadap jumlah daun, jumlah bunga betina, jumlah buah per tanaman, jumlah buah yang rusak dan gugur, bobot buah per tanaman, panjang buah, dan bobot kering brangkasan tanaman mentimun.

\begin{tabular}{|c|c|c|c|c|c|c|c|c|}
\hline \multirow{2}{*}{$\begin{array}{c}\begin{array}{c}\text { Dosis NPK } \\
\text { (g per polibag) }\end{array} \\
10\end{array}$} & \multicolumn{2}{|c|}{ Jumlah daun (helai) } & \multicolumn{2}{|c|}{$\begin{array}{c}\text { Jumlah bunga } \\
\text { betina }\end{array}$} & \multicolumn{2}{|c|}{$\begin{array}{l}\text { Jumlah buah per tanaman } \\
\text { (butir) }\end{array}$} & \multicolumn{2}{|c|}{$\begin{array}{l}\text { Jumlah buah yang } \\
\text { rusak dan gugur (butir) }\end{array}$} \\
\hline & 13,62 & $\mathrm{~b}$ & 4,97 & $\mathrm{~b}$ & 2,00 & $\mathrm{~b}$ & & $1,82 \quad b$ \\
\hline 20 & 19,23 & $\mathrm{a}$ & 16,57 & $\mathrm{a}$ & 5,97 & $\mathrm{a}$ & & $1,78 \quad b$ \\
\hline 30 & 17,93 & $\mathrm{a}$ & 13,03 & $\mathrm{a}$ & 5,21 & $\mathrm{a}$ & & 0,44 a \\
\hline BNT 0,05 & 3,01 & & 6,93 & & 1,52 & & & 0,60 \\
\hline $\begin{array}{c}\text { Dosis NPK } \\
\text { (g per polibag) }\end{array}$ & \multicolumn{3}{|c|}{$\begin{array}{l}\text { Bobot buah per tanaman } \\
\text { (gram) }\end{array}$} & \multicolumn{2}{|c|}{ Panjang buah $(\mathrm{cm})$} & \multicolumn{3}{|c|}{$\begin{array}{c}\text { Bobot kering brangkasan } \\
\text { (gram) }\end{array}$} \\
\hline 10 & 448 & $55 \mathrm{~b}$ & & & $65 \mathrm{~b}$ & & 3,87 & $\mathrm{~b}$ \\
\hline 20 & 118 & $41 \quad a$ & & & $83 \quad$ a & & 6,65 & a \\
\hline 30 & 1108 &, $09 \quad \mathrm{a}$ & & & $.63 \quad \mathrm{a}$ & & 6,45 & a \\
\hline BNT 0,05 & 227 &, 18 & & & 57 & & 1,64 & \\
\hline
\end{tabular}

Keterangan : Angka-angka yang diikuti oleh huruf yang sama tidak berbeda nyata dengan uji BNT pada taraf 5\%. 
Unsur K juga dapat meningkatkan kualitas hasil buah (rasa dan warnanya).

Dalam penelitian ini, pengaruh pupuk NPK lebih signifikan dalam meningkatkan pertumbuhan dan produksi mentimun. Meskipun pupuk NPK bersifat slow release namun ketersediaan unsur-unsurnya dapat segera dimanfaatkan oleh tanaman mentimun. Hal ini merupakan salah satu kelebihan pupuk anorganik yang responnya lebih cepat terlihat pada tanaman dibandingkan pupuk organik.

Pada penelitian ini pemberian pupuk NPK dengan dosis $20 \mathrm{~g} /$ polibag tanpa pupuk organik cair memberikan hasil bobot buah lebih tinggi dibandingkan dengan perlakuan $10 \mathrm{~g} /$ polibag yaitu 736,86 g atau sebesar 164 , $27 \%$ dan lebih tinggi 3,97 butir pada jumlah buah per tanaman atau sebesar $198,5 \%$. Sedangkan pemberian pupuk NPK yang dikombinasikan dengan pupuk organik cair memberikan hasil yang tidak berbeda nyata, hal ini kemungkinan disebabkan oleh pupuk kandang sapi yang dicampur sebagai media tanam. Maka untuk menghemat biaya produksi, sebaiknya gunakan pupuk NPK saja. Namun, perlu penelitian lebih lanjut untuk penggunaan pupuk organik cair pada tanaman mentimun dengan frekuensi pemberian yang lebih sering

\section{KESIMPULAN}

Kesimpulan dari penelitian ini menunjukkan bahwa pupuk organik cair tidak meningkatkan pertumbuhan dan produksi tanaman mentimun. Pemberian pupuk NPK (15:15:15) dengan dosis $20 \mathrm{~g} /$ polibag dan $30 \mathrm{~g} /$ polibag memberikan hasil yang lebih tinggi bagi pertumbuhan dan produksi tanaman mentimun dibandingkan dengan pemberian NPK dosis 10g/polibag, khususnya pada jumlah daun, jumlah bunga jantan, jumlah bunga betina, jumlah buah per tanaman, bobot buah per tanaman, panjang buah, dan bobot kering brangkasan tanaman mentimun. Pengaruh pemberian pupuk organik cair terhadap pertumbuhan tanaman mentimun dipengaruhi oleh pemberian pupuk NPK (15:15:15) hanya nampak pada variabel jumlah bunga jantan.

\section{DAFTAR PUSTAKA}

Badan Pusat Statistik (BPS). 2012. Produksi Sayuran di Indonesia. http://www.bps.go.id/tab_sub/ view.php?tabel $=1 \&$ daftar $=1$ \&id_subyek=55\&notab $=20$. Diakses pada tanggal: 16 Januari 2012.

Farida dan J.S. Hamdani. 2001. Pertumbuhan dan hasil bunga gladiol pada dosis pupuk organik bokashi dan dosis pupuk nitrogen yang berbeda. Jurnal Bionatura: Biologi Terapan. 3(2): 68-76.
Hamdani, J.S. 2008. Hasil dan kualitas hasil mentimun dengan aplikasi pupuk n-coated dan pupuk organik cair. Jurnal Agrivigor. 8(1): 15-23.

Hamdani, J. S., dan T. Simarmata. 2003. Pertumbuhan dan hasil jahe (Zingiber officinale Rose.) cultivar gajah yang dipanen muda pada berbagai jenis dan dosis pupuk organik dan anorganik. Jurnal Kultivasi. 2(2): 26-32

Indrakusuma. 2000. Proposal Pupuk Organik Cair Supra Alam Lestari. PT Suya Pratama Alam. Yogyakarta. $56 \mathrm{hlm}$

Nurhayati. 2012. Pengaruh perlakuan interaksi antara dosis dan waktu pemberian pupuk hayati majemuk cair bio extrim terhadap pertumbuhan dan produksi tanaman kentang (Solanum tuberosum L.). Jurnal STEVIA Universitas Quality. 2(1): 7-15.

Nurshanti, D.F. 2009. Pengaruh pemberian pupuk organik terhadap pertumbuhan dan hasil tanaman sawi caisim. Jurnal Agronobis. 1(1): 89-98.

Rohayati, M.A. 2007. Respon Tanaman Kentang (Solanum tuberosum L.) terhadap Pemberian Pupuk Organik Cair dan Kombinasi Pupuk Anorganik dengan atau Tanpa Pupuk Kandang Sapi. (Skripsi). Universitas Lampung. Bandar Lampung. $62 \mathrm{hlm}$

Sarno. 2009. Pengaruh kombinasi npk dan pupuk kandang terhadap sifat tanah dan pertumbuhan serta produksi tanaman caisim. Jurnal Tanah Tropika. 14(3): 211-219.

Septiyaning, Indah. 2011. Kemarau Hasil Panen Mentimun Menyusut. http://www.solopos.com/ 2011/karanganyar/kemarau-hasil-panenmentimun-menyusut-116147. SoloPos. Solo. Diakses pada tanggal : 19 Januari 2012.

Simarmata, T. 2005. Aplikasi pupuk biologis dan pupuk organik untuk meningkatkan kesehatan tanah dan hasil tanaman tomat (Lycopersicon esculentum Mill.) pada Inceptisols di Jatinangor. Jurnal Agroland. 12(3): 261-266.

Sudjianto, U. dan V. Krestiani. 2009. Studi dan dosis NPK pada hasil buah melon (Cucumis melo L.). Jurnal Sains dan Teknologi. 2(2): 70-77.

Sumpena, U. 2001. Budidaya Mentimun Intensif. Penebar Swadaya. Jakarta. $80 \mathrm{hlm}$.

Sutanto, R. 2002. Penerapan Pertanian Organik. Kanisius. Yogyakarta. $211 \mathrm{hlm}$. 
Sutejo,M.M. dan A.G. Kartasapoetra. 1995. Pupuk dan Cara Pemupukan. Rineka Cipta. Jakarta

Suwarno, V. S. 2013. Respon pertumbuhan dan produksi tanaman mentimun (Cucumis sativus L.) melalui perlakuan pupuk NPK pelangi. Jurnal Karya Ilmiah Mahasiswa Universitas Negeri Gorontalo. 1(1): 1-12.
Tuherkih, E. dan I. A. Sipahutar. 2010. Pengaruh pupuk majemuk NPK (16:16:15) terhadap pertumbuhan dan hasil jagung (Zea mays L.) di tanah Inceptisols. Jurnal Tanah dan Iklim. 3(23): 7890 